\title{
Regulation of collagenolysis and cell death by plasmin within the formative stigma of preovulatory ovine follicles
}

\author{
W. J. Murdoch \\ Department of Animal Science, University of Wyoming, Laramie, WY 82071, USA
}

\begin{abstract}
Collagen breakdown and apoptotic cell death within the apex of the preovulatory ovine follicle are characteristic of impending rupture. It has been hypothesized that plasmin regulates these two responses by activating collagenases and tumour necrosis factor $\alpha$ (TNF- $\alpha$ ), respectively. Apical plasmin bioactivity, collagenolysis, TNF- $\alpha$-mediated fragmentation of cellular DNA (a marker of apoptosis), stigma formation, and follicular rupture in sheep were inhibited by intrafollicular injection of $\alpha_{2}$-antiplasmin. Explants of follicular wall released hydroxyproline-containing peptides (degraded collagen) and bioactive TNF- $\alpha$ upon exposure to plasmin. These results indicate that plasmin has an essential intermediary role in the biomechanics of ovulatory ovarian tissue dissolution.
\end{abstract}

\section{Introduction}

Plasmin is a pleiotropic serine protease that is derived from the zymogen plasminogen by enzymic activation (Hart and Rehemtulla, 1988). The follicular plasminogen activatorplasmin system has been implicated in the mechanism of ovulation. It has been reported that plasmin activates collagenases which degrade the connective tissue matrices of the follicular theca and tunica albuginea, thereby weakening the ovarian wall to the point of papilla (stigma) formation and consequent rupture (Tsafriri and Reich, 1991). Plasmin production (Colgin and Murdoch, 1997) and collagenolysis (Murdoch and McCormick, 1992) are preferentially increased within the apical hemisphere of preovulatory ovine follicles.

Active physiological cell death that contributes to stigma formation is also enhanced within the follicular apex (Murdoch, $1995 a, b)$. Cleavage of bioactive (soluble) TNF- $\alpha$ exodomain from its membrane anchor on thecal endothelial cells is responsible for programming death (internucleosomal DNA fragmentation) among ovarian cells within a limited diffusion radius that encompasses the formative rupture site (Murdoch et al., 1997). TNF- $\alpha$ is a candidate substrate for serine protease, possibly plasmin, attack (Scuderi, 1989; Perona and Craik, 1995).

The objectives of this study in sheep were: (i) to determine if ovulation can be blocked by intrafollicular injection of the plasmin inhibitor $\alpha_{2}$-antiplasmin; (ii) to evaluate the effects of $\alpha_{2}$-antiplasmin on collagenolysis and apoptosis within the ovarian apex; and (iii) to assess the capacity of exogenous plasmin to affect collagen degradation and TNF- $\alpha$ release by the follicular wall.

\section{Materials and Methods}

Mature Western Range ewes were penned each day with vasectomized rams and observed for oestrous behaviour. The Received 28 October 1997. first day of oestrus was designated day 0 . On day 14 of the oestrous cycle, animals were injected i.m. with $10 \mathrm{mg}$ PGF $_{2 a}$ tromethamine (Lutalyse; Upjohn, Kalamazoo, MI) to synchronize luteal regression. A synthetic agonist of $\mathrm{GnRH}(5 \mu \mathrm{g}$, des $\mathrm{Gly}^{10}-\mathrm{Ala}^{6}$ ethylamide; Sigma Chemical Co., St Louis, MO) was administered i.m. $36 \mathrm{~h}$ after the PGF $_{2 u}$ injection to elicit a preovulatory surge of gonadotrophins; natural surges commence at approximately $40 \mathrm{~h}$. The follicle of greatest visible diameter within the pair of ovaries ovulates about $24 \mathrm{~h}$ after injection of GnRH and forms a normal corpus luteum (Roberts et al., 1985). Experiments were conducted with the approval of the University of Wyoming Animal Care and Use Committee.

\section{Experiment 1}

Ewes were anaesthetized $16 \mathrm{~h}$ after injection with $\mathrm{GnRH}$ using sodium thiopental administered i.v. and $20 \mu \mathrm{l}$ PBS or this vehicle containing $100 \mu \mathrm{g} \alpha_{2}$-antiplasmin (Sigma A0914, Sigma Chemical Co., St Louis, MO) was injected into the antral cavity of the dominant follicle $(n=6)$ during midventral abdominal laparotomy. Injections were made with a Hamilton syringe fitted with a 27-gauge hypodermic needle. The tip of the needle was inserted into the adjacent ovarian stroma and then directed into the antrum to avoid loss of follicular fluid through the site of puncture. Follicles were observed by laparoscopy for a rupture point (inferred ovulation) $32 \mathrm{~h}$ after injection with GnRH.

\section{Experiment 2}

Control or $\alpha_{2}$-antiplasmin intrafollicular injections were carried out as described previously $(n=5)$. Animals were killed using Beuthanasia (Schering-Plough, Kenilworth, NJ) administered i.v. $22 \mathrm{~h}$ after treatment with $\mathrm{GnRH}$ and the apical walls of follicles were isolated. Tissues were proportioned for morphometric, enzymic (plasmin and collagenase), and immunofluorescence (DNA strand-break, TNF- $\alpha$ ) analyses. Histological 

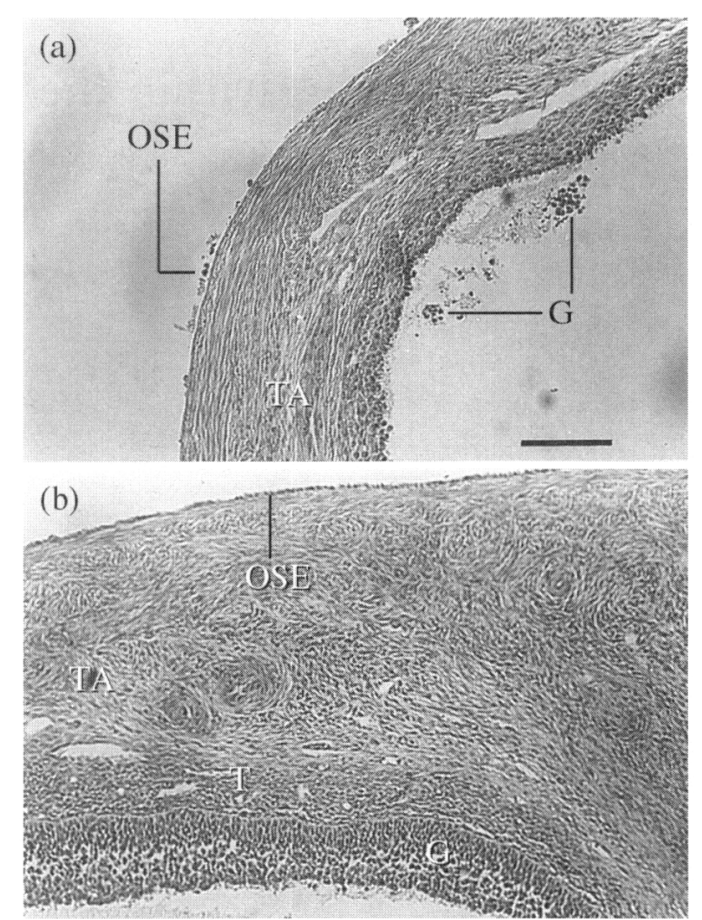

Fig. 1. Light photomicrographs of apical wall of (a) control and (b) $\alpha_{2}$-antiplasmin-treated ovine follicles. Note the dispersion of granulosal cells and lack of ovarian surface epithelium associated with preovulatory follicles. G, granulosa; OSE, ovarian surface epithelium; $T$, theca; TA, tunica albuginea. Scale bar represents $0.5 \mathrm{~mm}$.

observations were made with an Olympus BH-2 bright-field microscope equipped with photographic and reflected light fluorescence attachments.

The thickness of collagenous layers forming the ovarianfollicular interface (comprising tunica albuginea, theca externa and theca interna) were estimated from Histochoice (Amresco, Solon, $\mathrm{OH})$-fixed, paraffin-embedded, serial $(5 \mu \mathrm{m})$ crosssections of haematoxylin- and eosin-stained tissues. Measurements were made at six random sites per sample with the aid of Optimas (Bothell, WA) image analysis software.

Amidolytic cleavage of a plasmin-specific chromogenic substrate (H-D-norleucyl-hexahydrotyrosyl-lysine-p-nitroanilide diacetate salt) was used to assay plasmin bioactivity in $8 \mathrm{mg}$ tissue extracts as described by Colgin and Murdoch (1997). Collagenolytic activity of $10 \mathrm{mg}$ tissue homogenates was ascertained as a function of induced release of tritiated peptides from reconstituted collagen fibrils as described by Murdoch and McCormick (1992).

Ovarian surface epithelial and granulosal cells were removed from segments of follicular wall using a teflon scraper designed to recover adherent cells from culture flasks (Becton Dickinson Co., Lincoln Park, NJ). Isolated cells were transferred to subbed microscope slides in $50 \mu \mathrm{l}$ Histochoice, air-dried, and rinsed in two changes of PBS. An Oncor (Gaithersburg, MD) ApopTag S7110 kit was used to detect fragmented DNA in permeabilized cells according to the instructions of the manufacturer. This technique is more specific for apoptosis than necrosis (Gorczyca et al., 1993). Briefly, exposed 3'-OH ends of DNA fragments were labelled with digoxigenin-1 I-d uridine triphosphate by terminal deoxynucleotidyl transferase (TdT) catalysis.
Incorporated nucleotide heteropolymers were localized with antidigoxigenin Fab-fluorescein isothiocyanate and cells were lightly counterstained in propidium iodide. Images of individual cells ( $\geq 20$ per sample) were categorized as positively labelled (luminance intensity $>$ twice that of the control (-TdTconjugate) cell background) or not immunoreactive using the Optimas image analysis system.

Paraffin wax sections of residual follicular wall were processed for TNF- $\alpha$ immunostaining (Murdoch et al., 1997). Negative control reactions were performed in the absence of primary antibody and in the presence of antibody preabsorbed with TNF- $\alpha$. A minimum of six areas representing theca interna per sample were photographed (Ektachrome $400 \mathrm{HC}$; $40 \mathrm{~s}$ exposure; $\times 1000$ ) and classified as endothelial-discrete or diffusely fluorescent.

\section{Experiment 3}

The apical dome of the dominant follicle was removed from each of eight ewes ovariectomized $36 \mathrm{~h}$ after administration of $\mathrm{PGF}_{2 u}$. These animals were not stimulated with $\mathrm{GnRH}$ to elicit a gonadotrophin surge. Tissues $(20 \mathrm{mg})$ were incubated for $2 \mathrm{~h}$ at $37^{\circ} \mathrm{C}$ in $0.2 \mathrm{ml}$ Hank's balanced salt solution (Sigma Chemical Co., St Louis, MO) supplemented with 0.2 iu of native or heat-inactivated (control) bovine plasmin (Sigma P7911) $(n=4)$.

Hydroxyproline is an imino acid that is particularly abundant in collagen (Eyre et al., 1984). Hydroxyproline was quantified in conditioned media $(0.1 \mathrm{ml})$ using a standard colorimetric assay (Woessner, 1961; Murdoch and McCormick, 1993) as an index of collagenolysis.

In vitro induction by conditioned media of apoptosis in sheep ovarian surface epithelial cells was used as a bioassay for TNF- $\alpha$ (Murdoch et al., 1997). Surface cells were recovered from ovaries of lambs slaughtered in the University of Wyoming Meat Science abattoir. Cells were suspended in medium-199 (Sigma) at a concentration of $5 \times 10^{5} \mathrm{ml}^{-1}$ and aliquoted in $45 \mu \mathrm{l}$ increments into 96 -well culture plates. The cells were then incubated for $4 \mathrm{~h}$ at $37^{\circ} \mathrm{C}$ with $50 \mu \mathrm{l}$ culture media preabsorbed with $5 \mu \mathrm{l}$ TNF- $\alpha$ antiserum or nonimmune rabbit serum. Cells were transferred to microscope slides and evaluated ( $\geq 50$ cells per sample) for fragmented DNA.

\section{Statistical analyses}

Subsample data were averaged for each animal. Treatment means were contrasted by Student's $t$ test and differences were considered significant at $P<0.05$.

\section{Results}

\section{Experiment 1}

Ovulation was blocked in five out of six ewes that received an intrafollicular injection of PBS containing $\alpha_{2}$-antiplasmin. Rupture occurred in all six control follicles.

\section{Experiment 2}

A formative stigma was apparent on preovulatory follicles of control ewes. There was no manifestation of upcoming 


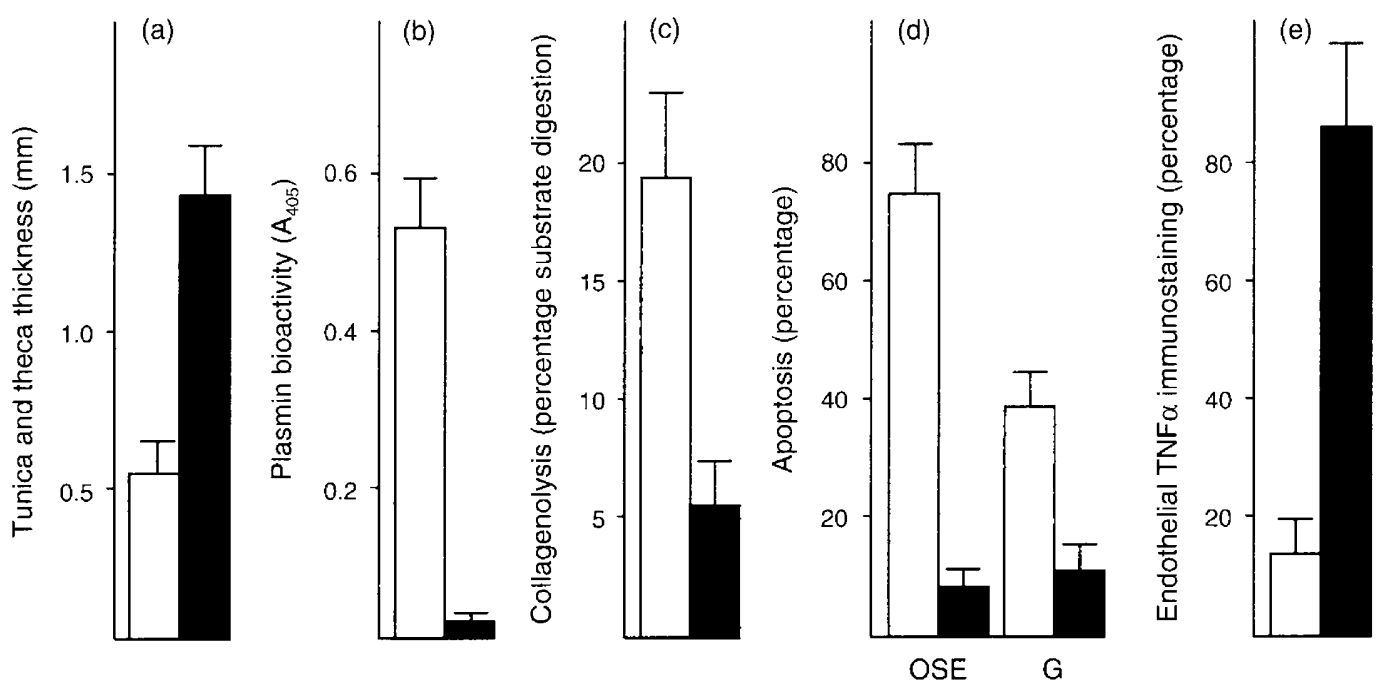

Fig. 2. Comparative effects of injection of ovine follicles with PBS ( $\square$, control) or $\alpha_{2}$-antiplasmin ( $\boldsymbol{\square}$ ) on: (a) thickness of the connective tissue layers of the apical ovarian wall $(P<0.01)$; (b) degradation of plasmin substrate by follicular extracts as quantified by the release of free $p$-nitroaniline monitored spectrophotometrically at an absorbance of $405 \mathrm{~nm}(P<0.01)$; (c) follicular-induced substrate collagenolysis as quantified by solubilization of radiolabelled collagen fragments isolated by centrifugation and counted by liquid scintillation spectroscopy $(P<0.05)$; (d) ovarian surface epithelial (OSE) and granulosal $(G)$ apoptosis $(P<0.01)$; and (e) thecal endothelial immunostaining $(P<0.01)$. Values are means \pm SEM.
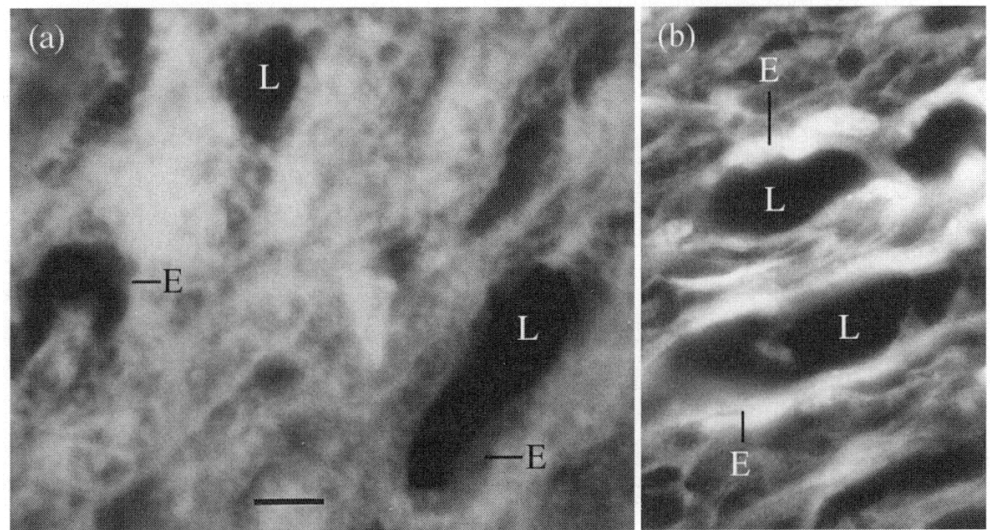

Fig. 3. Light photomicrographs of theca interna of (a) control and (b) $\alpha_{2}$-antiplasmin-treated ovine follicles. Note the dispersed (interstitial) tumour necrosis factor $\alpha$ immunostaining pattern and loss of vascular integrity in the control compared with the defined immunostained endothelia of the anovulatory follicles. E, endothelium; L, blood vessel lumen. Scale bar represents $20 \mu \mathrm{m}$.

ovulation from follicles injected with $\alpha_{2}$-antiplasmin. Therefore, these observations confirmed the results of Expt 1 .

Light microscopic examination (Fig. 1) of the apex of preovulatory follicles revealed a loss of ovarian surface epithelium in most cases; the majority of cells that were present were in the advanced stages of degeneration. Connective tissue dissolution and thinning of the tunica and thecal layers were evident along the formative ovulation site. The basement membrane that underlies the membrana granulosa of preovulatory follicles was difficult to discern and granulosal cells were often dispersed and pyknotic. In contrast, tissue specimens recovered from $\alpha_{2}$-antiplasmin-treated follicles contained a substantial connective tissue matrix (Fig. 2) bordered by intact ovarian surface and granulosal epithelial layers.

Plasmin bioactivity in follicular extracts was depressed by intrafollicular injections of $\alpha_{2}$-antiplasmin (Fig. 2). Collagenolytic activity of follicular tissue homogenates was inhibited by $\alpha_{2}$-antiplasmin (Fig. 2).

Evidence of nuclear DNA fragmentation (percentage apoptosis) was greater in ovarian surface and granulosal cells of control compared with $\alpha_{2}$-antiplasmin-treated follicles (Fig. 2). Corresponding sections of theca interna revealed that the majority of endothelial cells of follicles treated with $\alpha_{2}$-antiplasmin immunostained intensely for TNF- $\alpha$ whereas in 


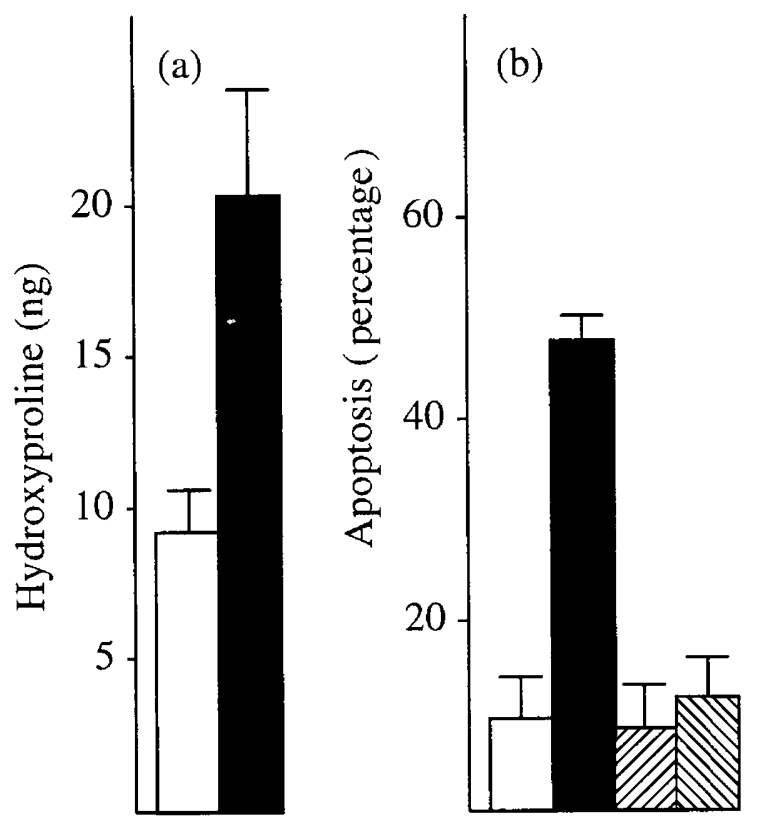

Fig. 4. Plasmin stimulation of (a) hydroxyproline (an indicator of collagen degradation; $P<0.05$ ) and (b) tumour necrosis factor $\alpha$ (TNF- $\alpha$ ) (ovarian surface cell apoptosis bioassay; $P<0.01$ ) release from explants of ovine ovarian wall. ( $\square$ ) Heat-inactivated control;

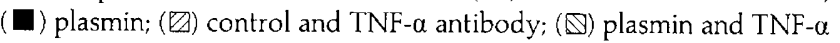
antibody. Values are means \pm SEM.

preovulatory follicles TNF- $\alpha$ was released into surrounding tissues (Fig. 3).

\section{Experiment 3}

Hydroxyproline and TNF- $\alpha$ were elevated in conditioned incubation media of follicular explants exposed to native plasmin. Plasmin-induced TNF- $\alpha$ bioactivity, as indicated by DNA fragmentation in ovarian surface epithelial cells, was neutralized by TNF- $\alpha$ antiserum (Fig. 4).

\section{Discussion}

The results of this study indicate that plasmin has an intermediary role in the proteolytic and cell death mechanisms of follicular stigma formation and ovulatory rupture in sheep. Activation of collagenases by plasmin has been reported (Danø et al., 1985; Tsafriri and Reich, 1991). However, this is the first report of the function of plasmin in the bioactivation of TNF- $\alpha$.

Secretion of tissue- and urokinase-type plasminogen activators by thecal and granulosal cells of gonadotrophin-stimulated follicles has been established (Tsafriri and Reich, 1991; Hägglund et al., 1996). Plasminogen activators are also produced by the ovarian surface epithelium. Apical upregulation of plasmin bioactivity in preovulatory ovine follicles has been attributed to secretion of a urokinase-type plasminogen activator by ovarian surface epithelial cells contiguous with the follicular wall (Colgin and Murdoch, 1997). Receptors for gonadotrophins have been detected on ovarian surface epithelial cells (Godwin et al., 1993), and these cells may respond by producing plasminogen activator (D. C. Colgin and W. J. Murdoch, unpublished). It has been suggested that diffusion of LH to the ovarian surface is a sequel to the acute hyperaemic reaction that occurs within preovulatory follicles (Cavender and Murdoch, 1988). Therefore, plasminogen activator of ovarian surface origin may augment plasmin formation on a localized basis. Previous studies have shown that plasminogen activator is preferentially elevated within the apices of preovulatory pig (Smokovitis et al., 1988) and rat (Peng et al., 1993) follicles, as it is in sheep follicles (Colgin and Murdoch, 1997). The present results are in agreement with previous experiments indicating that local ovarian administration of $\alpha_{2}$-antiplasmin suppresses ovulation rates in rats (Tsafriri $e t$ al., 1989). In mice, the efficiency of ovulation is only impaired when both plasminogen activator gene functions are inactivated ( $\mathrm{Ny}$ et al., 1997). This suggests that in this species there are functionally redundant mechanisms for plasmin generation and the amount required for optimal ovulatory rate is normally exceeded.

TNF- $\alpha$ is expressed as a $26 \mathrm{kDa}$ integral transmembrane precursor molecule that yields a $17 \mathrm{kDa}$ extracellular domain subunit after proteolytic cleavage. Mature cytotoxic TNF- $\alpha$ is a noncovalent trimer. Common cell types known to produce TNF- $\alpha$ include leucocytes, smooth muscle, fibroblasts and endothelium. Plasma membrane receptors for TNF- $\alpha$ are present on virtually all nucleated cells (Vilcek and Lee, 1991; Vandenabeele et al., 1995). In addition to inducing lytic cell death (haemorrhagic necrosis), TNF- $\alpha$ can transduce an apoptotic signal that results in programmed cell death which is characterized by endonuclease activation, internucleosomal DNA fragmentation, and nuclear and cytoplasmic condensation (Larrick and Wright, 1990; Haanen and Vermes, 1995; Steller, 1995). Ovarian surface epithelial cells are typically the first cells of the impending rupture site to dissipate. The cells become pyknotic, lose contact with neighbouring cells and basement membrane, and are sloughed into the peritoneal cavity (Murdoch, 1994).

There is increasing evidence to implicate TNF- $\alpha$ in female reproductive functions. TNF- $\alpha$ or receptor sites for the protein have been identified in ovaries of several mammalian species (Terranova, 1997). Ovulation rates are enhanced by addition of TNF- $\alpha$ to perfusates of rat ovaries (Brännström et al., 1995). Intrafollicular injection of TNF- $\alpha$ antibodies blocks apical follicular apoptosis and ovulation in ewes (Murdoch et al., 1997). These findings suggest that TNF- $\alpha$ is an obligatory component of the ovulatory mechanism.

Mechanisms regulating TNF- $\alpha$ expression and release from resident ovarian cells are largely unknown. It is unlikely that gonadotrophin has a direct stimulatory effect, but rather its effect is mediated by other agents produced in response to hormonal stimulation (Terranova, 1997). In sheep, it appears that follicular plasmin is capable of liberating TNF- $\alpha$ from the surface of thecal endothelial cells. At high tissue concentrations, TNF- $\alpha$ initiates microvascular coagulation associated with necrotic cell death (Larrick and Wright, 1990) and inflammatory tissue damage symptomatic of the ovulatory process (Espey, 1980). Vascular lesions indicative of haemorrhagic necrosis are observed within the stigma of preovulatory ovine follicles (Cavender and Murdoch, 1988; Murdoch and Cavender, 1989). Figure 5 is a summary of the putative interactions of 
Proteolysis + Apoptosis $\longrightarrow$ Stigma $\longrightarrow$ Rupture

Ovarian surface epithelium Basement membrane

Tunica albuginea

Theca externa

Theca interna

Basement membrane

Follicular antrum

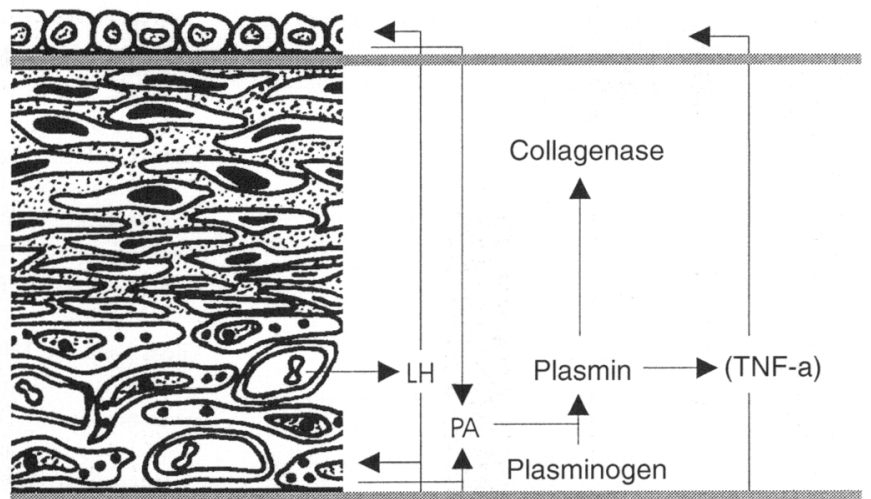

Granulosa
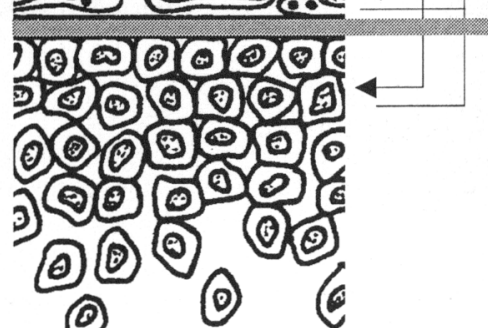

Fig. 5. Working model of proposed interactions of $\mathrm{LH}$, ovarian cell types, plasminogen activator (PA) and plasmin, and tumour necrosis factor $\alpha$ (TNF- $\alpha$ ) in the breakdown of the apical follicular wall during ovulation. Vascular transudate containing gonadotrophin is delivered to receptor-bearing cells (that is, granulosa, theca interna and surface epithelium) of the ovarian wall, thereby stimulating secretion of plasminogen activator; interstitial plasminogen is converted to plasmin, which activates latent collagenases and cleaves TNF- $\alpha$ from its endothelial mooring; collagenase disrupts the fibril network of the theca and tunica albuginea and promotes dissolution of the basement membranes supporting the ovarian and granulosal epithelia; TNF- $\alpha$ induces apoptosis; collagenolysis and cell deletion precipitate follicular rupture.

gonadotrophin, apical ovarian cell types, plasminogen activator and plasmin, and TNF- $\alpha$ in the ovulatory process.

This research was supported by USDA grant 95-37203-2131. Assistance with animal surgeries provided by E. A. Van Kirk is appreciated. Antiserum against TNF- $\alpha$ was kindly supplied by John Ellis (Western College of Veterinary Medicine, University of Saskatchewan, Saskatoon, Canada).

\section{References}

Brännström M, Bonello N, Wang LJ and Norman RJ (1995) Effects of tumour necrosis factor $\alpha$ on ovulation in the rat ovary Reproduction Fertility and Development 7 67-73

Cavender JL and Murdoch WJ (1988) Morphological studies of the microcirculatory system of periovulatory ovine follicles Biology of Reproduction 39 989-997

Colgin DC and Murdoch WJ (1997) Evidence for a role of the ovarian surface epithelium in the ovulatory mechanism of the sheep: secretion of urokinasetype plasminogen activator Animal Reproduction Science 47 197-204

Dane K, Andreasen PA, Grondahl-Hansen J, Kristensen P, Nielsen LS and Skriver L (1985) Plasminogen activators, tissue degradation, and cancer Advances in Cancer Research 44 139-266

Espey LL. (1980) Ovulation as an inflammatory reaction - a hypothesis Biology of Reproduction 22 73-106

Eyre DR, Paz MA and Gallop PM (1984) Cross-linking in collagen and elastin Annual Review of Biochemistry 53 717-748

Godwin AK, Testa JR and Hamilton TC (1993) The biology of ovarian cancer development Cancer 71 530-536
Gorczyca W, Bigman K, Mittelman A, Ahmed T, Gong J, Melamed MR and Darzynkiewicz Z (1993) Induction of DNA strand breaks associated with apoptosis during treatment of leukemias Lerkemia 7 659-670

Haanen C and Vermes I (1995) Apoptosis and inflammation Mediators of Inflammation 4 5-15

Hägglund A-C, Ny A, Liu K and Ny T (1996) Co-ordinated and cell-specific induction of both physiological plasminogen activators creates functionally redundant mechanisms for plasmin formation during ovulation Endocrinology $1375671-5677$

Hart DA and Rehemtulla A (1988) Plasminogen activators and their inhibitors: regulators of extracellular proteolysis and cell function Comparative Biochemistry and Physiology 90B 691-708

Larrick JW and Wright SC (1990) Cytotoxic mechanism of tumor necrosis factor- $\alpha$ FASEB Journal 4 3215-3223

Murdoch WJ (1994) Ovarian surface epithelium during ovulatory and anovulatory ovine estrous cycles Anatomical Record 240 322-326

Murdoch WJ (1995a) Programmed cell death in preovulatory ovine follicles Biology of Reproduction 53 8-12

Murdoch WJ (1995b) Endothelial cell death in preovulatory ovine follicles: possible implication in the biomechanics of rupture Journal of Reproduction and Fertility 105 161-164

Murdoch WJ and Cavender JL (1989) Effect of indomethacin on the vascular architecture of preovulatory ovine follicles: possible implication in the luteinized unruptured follicle syndrome Fertility and Sterility 51 153-155

Murdoch WJ and McCormick RJ (1992) Enhanced degradation of collagen within apical vs basal wall of ovulatory ovine follicle American Journal of Physiology 263 E221-E225

Murdoch WJ and McCormick RJ (1993) Mechanisms and physiological implications of leucocyte chemoattraction into periovulatory ovine follicles Journal of Reproduction and Fertility $97375-380$

Murdoch WJ, Colgin DC and Ellis JA (1997) Role of tumor necrosis factor- $\alpha$ in the ovulatory mechanism of ewes Journal of Animal Science 75 1601-1605 
Ny A, Nordström L, Carmeliet P and Ny T (1997) Studies of mice lacking plasminogen activator gene function suggest that plasmin production prior to ovulation exceeds the amount needed for optimal ovulation efficiency European Journal of Biochemistry 244 487-493

Peng X-R, Hsueh AJW and Ny T (1993) Transient and cell-specific expression of tissue-type plasminogen activator and plasminogen-activator-inhibitor type 1 results in controlled and directed proteolysis during gonadotropin-induced ovulation European Journal of Biochemistry 214 147-156

Perona JJ and Craik CS (1995) Structural specificity in the serine proteases Protein Science 4 337-360

Roberts AJ, Dunn TG and Murdoch WJ (1985) Induction of ovulation in proestrous ewes: identification of the ovulatory follicle and functional status of the corpus luteum Domestic Animal Endocrinology 2 207-210

Scuderi P (1989) Suppression of human leukocyte tumor necrosis factor secretion by the serine protease inhibitor $p$-toluenesulfonyl-L-arginine methyl ester Journal of Immunology 143 I68-173

Smokovitis A, Kokolis N and Alexaki-Tzivanidou E (1988) The plasminogen activator activity is markedly increased mainly at the area of the rupture of the follicular wall at the time of ovulation Animal Reproduction Science 16 285-294
Steller H (1995) Mechanisms and genes of cellular suicide Science 267 14451449

Terranova PF (1997) Potential roles of tumor necrosis factor- $\alpha$ in follicular development, ovulation, and the life span of the corpus luteum Domestic Animal Endocrinology 14 1-15

Tsafriri A and Reich R (1991) Plasminogen activators in the preovulatory follicle: role in ovulation. In Plasminogen Activators: From Cloning To Therapy pp 81-93 Eds R Abbate, T Barni and A Tsafriri. Raven Press, New York

Tsafriri A, Bicsak TA, Cajander SB, Ny T and Hsueh AJW (1989) Suppression of ovulation rate by antibodies to tissue-type plasminogen activator and $\alpha_{2}$-antiplasmin Endocrinology 124 415-421

Vandenabeele P, Declercq W, Beyaert $\mathbf{R}$ and Fiers W (1995) Two tumour necrosis factor receptors: structure and function Trends in Cell Biology 5 392-399

Vilcek J and Lee TH (1991) Tumor necrosis factor Journal of Biological Chemistry $2667313-7316$

Woessner JF (1961) The determination of hydroxyproline in tissue and protein samples containing small proportions of this amino acid Archives of Biochemistry and Biophysics $9344-447$ 